\title{
A pastoral investigation into some of the challenges associated with aging and retirement in the South African context
}

\begin{abstract}
Author:
Magezi E. Baloyi ${ }^{1}$

Affiliation:

${ }^{1}$ Practical Theology,

University of South Africa,

Pretoria, South Africa

Correspondence to:

Magezi Baloyi

Email:

baloye@unisa.ac.za

Postal address:

PO Box 329, Unisa 0003,

South Africa

\section{Dates:}

Received: 21 July 2014

Accepted: 16 Sept. 2015

Published: 18 Nov. 2015

How to cite this article: Baloyi, M.E., 2015, 'A pastoral investigation into some of the challenges associated with aging and retirement in the South African context', In die Skriflig 49(3), Art. \#1866, 10 pages. http://dx.doi. org/10.4102/ids.v49i3.1866

\section{Copyright:}

(C) 2015. The Authors.

Licensee: AOSIS

OpenJournals. This work is

licensed under the Creative

Commons Attribution

License.
\end{abstract}

Read online:

$$
\begin{aligned}
& \text { Scan this QR } \\
& \text { code with your } \\
& \text { smart phone or } \\
& \text { mobile device } \\
& \text { to read online. }
\end{aligned}
$$

This article is a contribution to a project that congratulates from the work of George Lotter, a pastor, pastoral counsellor and academic who wrote much on matters relating to pastoral care and counselling. Elderliness and retirement can be understood as a period in the lives of elderly people that allows them to rest after a long life of activity and service. From another point of view, old age is also a time that offers pastoral caregivers an opportunity to care for people who have contributed to their families and society. Pastoral caregivers have an important role to play in the lives of elderly people. This applies particularly to elderly black South Africans, who often find themselves confronted by poverty and other related problems. This article investigates the challenges and problems affecting retired and elderly black South Africans with particular focus on the economic impact of aging and its influence on family relationships in the lives of elderly people. To conclude: it is the duty of pastoral caregivers to search for and establish guidelines for the roles the church can play in improving elderly people's quality of life.

'n Pastorale ondersoek na enkele van die uitdagings ten opsigte van veroudering en aftrede in die Suid-Afrikaanse konteks. Hierdie artikel is ' $n$ bydrae tot 'n projek wat voorspruit uit die werk van George Lotter, 'n pastor, pastorale berader en akademikus wat baie geskryf het oor kwessies wat met pastorale sorg en berading verband hou. Bejaardheid en aftrede kan verstaan word as 'n tyd in in ouer persone se lewe waartydens hulle kan rus ná 'n lang aktiewe en diensbare lewe. Bejaardheid kan ook gesien word as 'n tyd wat aan pastorale versorgers die geleentheid gee om na die mense wat bygedra het tot hulle families en die gemeenskap se versorging, om te sien. Pastorale versorgers speel 'n belangrike rol in die lewens van bejaardes. Dit is spesifiek van toepassing op bejaarde swart Suid-Afrikaners wat dikwels gekonfronteer word met armoede en aanverwante probleme. Hierdie artikel ondersoek die uitdagings en probleme waarmee bejaarde swart Suid-Afrikaanse afgetredenes te kampe het. Dit fokus spesifiek op die ekonomiese uitwerking van veroudering en die invloed wat dit op familieverhoudinge in die lewens van bejaardes het. Die slotsom word gemaak dat dit die plig van pastorale versorgers is om riglyne te soek en te bied vir die rol wat die kerk kan speel ter verbetering van die lewensomstandighede van die bejaardes.

\section{Introduction}

The plight of the elderly people who are raped, robbed and abused in South Africa, particularly amongst the black Africans, is the concern this article intends to address. From a practical theological point of view it is imperative that theology and the church cannot continue to turn a blind eye and fold up their arms whilst the senior citizens of this country are under such tremendous violence. Theology is only deemed relevant if it deals with the challenges faced by human beings in their individual situations. Besides creating tensions and solidarity, human suffering must be realised as a theological issue (Dreyer \& Van der Ven 2002:45). It is very difficult to imagine our society without elderly people. It is for this reason that this article will argue that the abuse and violence against elderly people is a pathology that does not only need to be arrested, but also to be destroyed. From the practical point of view magazines, media statements, newspapers and other media means will be utilised to gather the information relevant to elderly abuse. These plights and challenges of elderly people, particularly black Africans (in South Africa), will be formulated, and pastoral advises and suggestions will follow afterwards.

For Brunsdon and Lotter (2008:285) retirement can be viewed as a critical life-phase, which offers a challenge to caregivers. Larney and Lotter (2005:661) saw the importance of the parental role in the process of instructing, modelling and transmitting moral and ethical values to younger 
generations. Their conviction that elderly people have an important role to play in society is an important element to the realisation that elderly people need to be assisted to realise their continuing worth and potential. Whilst some elderly people are congratulated and rewarded for their good works, other elderly black Africans find themselves abused, accused of witchcraft or left abandoned and homeless (World Health Organisation 2015:2).

The importance of this contextual study is, amongst others, motivated by the neglect and abuse of the elderly black people, which is becoming a common practice both in rural and urban areas. Theron (2014) argues that they are often treated as 'human waste in their later years'. One of the reasons why elderly people are neglected, abused and even killed is the stereotypes people have on them. Ferreira and Lindgren (2008:96) support this by arguing that there is a lot of evidence that elderly people are often neglected in their communities. This is the most critical concern of this article. In practical terms, for many South African people, getting old brings a number of challenges. As one elderly woman put it:

I don't think I want to go and live with a child. I don't think I would want that. I think that then you become a nuisance and a burden and you are not loved so much because you are just these things. (Arber \& Evandrou 1993:53; Theron 2014:6)

Although this quotation was taken from a different background and context, it expresses a feeling also shared by many elderly black people in South Africa when they find themselves dependent on their children. That is why some elderly persons think that they are treated like 'human waste' (Theron 2014:2). Elderly people are often no longer able to manage without assistance, which results in situations in which they think they burden people when they need help, and therefore causes them unhappiness. For example, elderly people who are no longer able to maintain their own personal hygiene may have to rely on others to do it with the result that they feel unloved. Their self-image can be affected in consequence. Pastoral caregivers must be alert to the emotional and/or intellectual ramifications of this problem amongst others.

A further cause for concern is the fact that elderly people can find themselves forced to spend their pensions on family members instead of being able to spend the money on their own comfort and wellbeing. I witnessed this myself during a missionary visit to an elderly blind member of the Reformed church who lived with her 45 year old unmarried and unemployed son. The woman received her pension the previous week and yet she was left with almost nothing, having had to spend virtually all her money on food for the household. The government grants paid to pensioners are often used to support other people (Hosegood \& Timaeus 2006:1). Many people in the developing world hold informal jobs or do not earn a living wage in rural areas, with the result that elderly people often do not have the benefit of a proper pension after their retirement. Hosegood and Timaeus (2006:1) report that, in many instances, elderly people carry the burden of grandchildren whose parents passed away because of HIV and AIDS related illnesses.

One example is the story of 77-year-old Madala Elias Ntimane, as reported by Langa (2014). This man applied for a house as promised in terms of the South African government's Reconstruction and Development Programme (RDP) in 2009, but eventually gave up on that. At the time of this writing he was living in a shack near Tonga in Mpumalanga. He was quoted by Langa (2014):

Giving up on this government was the best decision ever. The day I decided not to trust politicians to give me a house, water, electricity, school and clinic was the day I saved my life. All my life I have lived in a shack. (p. 7)

This is but one of many instances in which elderly people in this country have been denied proper shelter and, in consequence, compromised their health and dignity. Many elderly black South Africans continue to be concerned about the problem of adequate shelter.

Worsfold (2005:3) contends, correctly in my view, that the management of the aging process is culture-specific. It is for this reason that this article focuses not on elderly people in general terms, but specifically on elderly black South Africans, whose concerns have been published widely (Ferreira \& Lindgren 2008:97). However, this article also aims to argue that the church has a role to play in bettering the lives of these senior citizens through its pastoral services.

\section{Theoretical argument and relevance of the study}

In recent years a number of non-governmental organisations (NGOs) have emerged the focus on the needs of the elderly people in this country. They include the South African Council for the Aged (Joubert, Swart \& Reddy 1998), the Institute of Aging in Africa (formerly Gerontology) (Conradie \& Charlton 1992:21) in collaboration with the Department of Welfare. They show at least that there is a perceived need to address the issue.

The rights of older people are clearly spelt out in the Older Persons Act 13 (Republic of South Africa 2006), but it is worrying that elderly people's status and respect continue to be undermined by abuse, rape and a range of the other social ills presently rife in South Africa. In brief, the Act asserts that the rights of an older person are defined by the Constitution (Republic of South Africa 1996:8). As Bigombe and Khadiagala (2003:19) showed, even before the advent of democracy in South Africa, large-scale urbanisation was resulting in a situation in which younger generations, who had traditionally cared for older persons, migrated to cities, leaving some aged people on their own. Since then, grandparents' pensions have become a major source of support funds for grandchildren in post-apartheid South Africa. 
Theology must always deal with the lives of people in their own context. From the practical theological point of view, the praxis of pastoral caregivers is believed to make a crucial difference to the lives of a range of people in need (Steyn \& Masango 2011:2).

\section{Definition of ageing}

According to the Longman Dictionary of Contemporary English (Summers \& Gadsby 2001:25), aging is the process of a person getting or becoming old, and usually involves their becoming less attractive. Waruta and Kinothi (2000:194), and Kirkwood (2005:1) define aging as a process characterised by a gradual deterioration of the structures and functions of the body, resulting in an increased susceptibility to accident and disease.

A Tsonga saying, Ku kula iku thelela evuhlangini [to grow is to return to childhood] finds an echo in the work of Waruta and Kinothi (2000:196), who state that, in many societies, old age is often viewed as a second childhood, because old people are considered to lose their ability to think logically and become forgetful. As a person ages, their immune system is weakened, they are more likely to develop heart disease, their memory begins to fail and changes in their sensory organs take place. It is for this reason that Kirkwood (2005:2) terms aging as 'the age of decline'.

Along with all this, it is generally assumed that elderly people have fewer needs than they had when they were younger. However, I would argue that elderly people have similar needs to those of other members of the society, and that their needs, in fact, require even more attention, because some of them may no longer be able to look after themselves and others may be ill or generally infirm.

\section{A brief background}

According to Hosegood and Timaeus (2006:1) the proportion of elderly people in South Africa, as a percentage of the population, is greater than in any other sub-Saharan African country. In circa (1997) older people constituted some $6 \%$ of the population, and projections at the time were that they would constitute $11 \%$ of the population in 2030 (Kinsella \& Ferreira 1997:1). At present, approximately 8.4\% (4.54 million) people are 60 years or older, according to mid-year population estimates in 2014 (Zingoni 2014:1). It is clear that the number of elderly people or senior citizens is growing, and that attention must be paid to their quality of life.

In some African countries, aging is generally associated with retirement and the receipt of a pension. It is expected that older people will be exempted from normal labour and allowed to rest from active economic duties. Waruta and Kinothi (2000:195) say that from an economic point of view, aging is often viewed as a process of becoming less active and productive, even to the point of being inactive and unproductive, as the health and economic status of elderly people prevents them from doing hard work and generating income for their families.
It is in light of Waruta and Kinothi's view above that I would partially agree with De Beer (2011:805), arguing that God created man as an ever working being. In a certain sense there is truth in this view, but on the other hand it could similarly be argued that God also created time to rest. Indeed, rest was an important part of the creation story in the Genesis. In my view, De Beer can be understood to say that people are urged to serve or work for God without retirement, whilst at the same time we need to recognise that human beings can become incapable of active labour or other work in an active, secular world.

\section{As Ramashala (2014) puts it:}

Because the incidence of chronic illness and disability increases with age, the longer one lives, the more likely one is to experience illness and disability. Chronic illness and disability, in turn, increase the likelihood that many very old people will no longer be able to live independently but will require care. (p. 19)

Older age is also a period of life when people need more medical attention and caring assistance, which is usually provided by closer relatives. This is one reason why black Africans often seek to ensure that at least one male child in the family does not abandon his parents by going away, but instead takes on responsibility for the care of the elderly members of that family. To substantiate this, Mbiti (1991:115) argues: 'When parents become old and weak it is the duty of the children, especially the heirs or sons, to look after the parents and the affairs of the family.' There are different forms of care, for example to cook, shop, clean and other practical domestic responsibilities. In South Africa the government provides elderly people with an old-age pension, which is aimed at helping senior citizens to buy clothing, good quality food and other necessities, because they are usually no longer able to seek a job and work for a salary. It therefore cause concern that many elderly people are required to assume the dual roles of carer and breadwinner for the family by actively taking care for adult children and covering their expenses (Legido-Quigley 2003:1). A person's pension is usually related to the income they earned whilst working (Arber \& Evandrou 1993:46), but in South Africa the amount paid is far below the salaries elderly people earned during their working lives. People must therefore expect to be poorer after their retirement. Despite the availability of the social grants elderly people receive most of them remain poor, because the expenditure of taking care of the family is too high.

Prior to the current democratic dispensation, most black South Africans worked for low salaries and therefore could not afford to build themselves good houses. In consequence they lived out their old age in shelters and shacks, because the government pension barely covered their basic needs. Ramashala (2014:2) points out that the number of older people in South Africa continues to grow and that their needs for economic security, access to health and human services, adequate housing and personal safety continue to require attention. Elderly people suffer, as a 
result, of the lack of proper housing or shelter. In this context Gordon (2013:1) cites the example of a 74-year-old woman who said that she had been waiting for an RDP house for so long that she had lost hope in the government, whilst other people like her, died whilst still waiting for those houses.

\section{Exploring challenges of elderly African people Introduction}

The challenges faced by South African elderly people are often neglected and sometimes ignored, because not many pastoral givers take interest in considering their issues as matters of importance. This sub-chapter is going to focus on unveiling some of the challenges these elderly people have to deal with.

\section{Post-retirement health care cost problem}

Although many people have free access to health care in South Africa, elderly people, who need some specialised form of health care because of their age, are not covered by many of the medical aid schemes. Most hospital cash back plans do not cover people over the age of 65 years (SA Hospital Plan 2005:1). Unlike a medical aid that cannot discriminate against a person based on age, hospital cash back plans are insurance policies. Insurance companies have to bear greater risk with this age group and will therefore not offer cover for the insurance of older people becomes expensive. Aging exposes people to a range of health problems. The poor health often experienced by the aged and the retired is exacerbated by high medical aid costs. Myeza (2010:2) noted that although some retirement funds appear to be improving the quality of medical aid for pensioners, the majority of pensioners lacked this service $-75 \%$ of the retirement funds do not offer such benefits.

\section{Accusations of witchcraft}

In a recent incident, an old woman was forced to jump a wall and run for her life in Mndeni (Soweto) after attackers threatened to burn her, because they claimed that she had bewitched their child. The old woman, whose name was given as Hazel, was quoted as saying: 'They wanted to beat me in front of the police, saying I was bewitching their child' (Sibiya 2014:4). Unfortunately, incidents of this kind where older people being accused of witchcraft still occur frequently in South Africa.

Amongst black South Africans, accusations of witchcraft are levelled at the old aged more than at any other age group. Dovlo (2007:77) states that in black African communities, 'older', single women are often suspected of witchcraft. 'All over Africa, including South Africa, older people, and especially women, are accused of witchcraft by virtue of their advanced age', says Worsfold (2005:xi). In consequence, some people resist being identified or labelled as old aged out of fear of being accused of witchcraft.

\section{Poverty and unemployment of the family members burdens the pensioner}

Myeza (2010:20) cites the widespread assumption that older persons' debts will be settled and their children will be selfsupporting by the time they retire, leaving them as the sole beneficiaries of the monthly pension. However, this is rarely the case. In South Africa, the majority of the population, black people in particular, live in poverty and retire in poverty.

Unemployment in South Africa is an undeniable reality for many people, even for those who have families and children to take care of. The result is that elderly people who receive grants or other retirement benefits often find themselves burdened with the responsibility of caring for children or grandchildren. For some families, an elderly person's pension is the family's only source of income. A pensioner may have no choice but to use this small amount of money to support the family (Legido-Quigley 2003:12; Moller \& Sotshongaye 1996:4). The South African old-age pension is too small to be an effective measure of poverty eradication, but it is still regarded as a major source of income to support poor families (Lam, Leibbrandt \& Ranchhod 2006:1). This makes unemployment one of the causes for desertion of the old aged by the middle-aged and young people.

\section{Fatherless children as a burden on the pensioner}

Children with deceased fathers and children who have been abandoned by their fathers become a burden to take care of and to be provided with a decent education. Ernest (2003:24) conducted extensive research into the effects of divorce on children globally by identifying a large number of problems that resulted from the separation of parents. Of relevance to this article is the fact that divorce results in many children being raised in single-parent households, and their financial support is often inadequate. In such situations, where single parents have parents who receive a pension, the pensioner would try to reduce the burden on his or her child by using the little money he or she receives to ensure that the children in the household receive education, shelter, food and clothing. In fact, this means that the pensioner is responsible for supporting the family financially.

Similarly, there are children whose fathers have abandoned them by being unfaithful to their mothers; this is frequently experienced by both adult women and teenage girls. Shefer and Clowes (2012:538) conducted a qualitative study on the experience of 29 young men who grew up without their biological fathers as a result of abandonment. Grandparents were often obliged to use their pension to help them.

\section{Elderly people taking care of orphans}

Khomo (2014:14) reports the heart-breaking story of a family in KwaZulu-Natal where the death of the three adult children left seven children in the care of their grandparents. This is one of the mostly disturbing challenges elderly people have to deal with, particularly in the black communities. 'In the 
last two years the burden has increased', the report reads. 'The kids are growing up and have started attending high school. This means they need more expensive items and more expensive support.' In another case in Emadakeni, near Queenswood, an old woman was left to care for all her grandchildren solely from her pension after her three daughters died. The extent of the financial burden forced the children to stop attending school because of the unaffordability of school uniforms and other relevant items (Thukwayo 2014:15). This is just one case, but there are many children who have to discontinue their studies due to this problem - particularly in areas where the community forums, who should watch over the orphans, are not functional.

In South Africa, elderly people frequently find themselves in the position where they have to use their pensions to support orphaned children whose parents died for any one of a range of reasons. In particular, the high incidence of HIV and AIDS in this country is costing the lives of many black people often those in an age group that would, under normal circumstances, be taking care of their own children. Elderly people are therefore left with no other choice but to take on the responsibility of care for their grandchildren.

Mr Mdiya (65) from Lamontville Township in KwaZuluNatal, for example, was forced to take care of his five grandchildren with the old-age pension he received from the government, because their parents died. The children were still of primary school age. He was quoted in HelpAge (n.d.):

I receive $\mathrm{R} 820$ a month, and I spend the money on bills - water, electricity, rates and food for the children. I also pay for the transport for other members of the family to come to the city (Durban) and visit. I also pay for my grandchildren's school fees, school uniforms and fill their lunch boxes because their parents have passed away. The pension needs to be double the amount to live more comfortably. (p. 2)

Although Theron's research (2014) was done in the Potchefstroom area, particularly within the old age institutions (predominately white elderly people), some of the problems, which were indicated as encountered by the elderly, are similar to those encountered by black elderly people in their respective rural communities. Theron (2014:6) confirms that these are a few cases out of many where older people have to look after their orphaned grandchildren whose parents died of HIV and AIDS. The challenge to make the situation better is mostly to ask for the children to be registered in order to receive social grant. This means the old aged who live with these orphans should get a form from a community assistance to ensure that these children are registered. The collaboration of the social workers and the church should also ensure that the orphans do not only become the burden of their elderly grandparents, but also of the church and government. This can be made by regular visits to ensure that the children's social grants as well as the assistance from the church's diaconal services are monitored to the benefit of these children. The South African government is trying its best to make social grants available for the orphans, but the church and the social workers should do their part by regular visits as well as ensuring that the grants are utilised for the upbringing of the children. This is in line with Theron's suggestion (2014:6) that elderly people should be assisted to register these children for the social grants.

\section{Experience of loneliness}

Some older people complain about feeling forgotten by friends and family. In some cases, loneliness occurs, because elderly people do not receive regular visits and have no one to talk to after younger members of the family choose to relocate to urban areas in search of jobs. In other cases, elderly people are left alone, because they, themselves, have chosen to remain in their traditional homes or villages for a variety of reasons (Davey 2006:128-141). De Haan (2005:162) is only partially correct in arguing that, in some cases, relocation is the reason why younger people do not accept the responsibility for the caring of aging parents. This may be true in some cases, but in others it is the parents who do not wish to join their children in the cities and towns, because they prefer to remain in the villages and continue to engage in the activities they are used to. That is why the black elderly people who are in the local day care centres, mentioned by Theron (2014:5), are doing well and look happy. They have regular interaction with their families, relatives and community.

Joubert and Brandshaw (2005) make an insightful comment:

At the familial or household level, internal migration may affect older persons; this can be either beneficial, when older persons are in receipt of remittances from working relatives, or disadvantageous, when they lose their traditional care-giving base as children migrate. (p. 206)

The pattern of migration is presently common in South Africa, where members of the younger generation relocate to urban areas to seek employment and where they end up owning or renting smaller properties to accommodate themselves alone - leaving elderly people living lonely lives in the traditional rural areas. The social isolation experienced by older people is often associated with a sense of confusion, particularly in those who suffer from chronic illnesses (Roos \& Malan 2012:2).

According to SAinfo Reporter (2014), the proportion of people, living in rural areas, dropped from $48 \%$ to $38 \%$ between 1990 and 2011, whilst the migration of people from rural to urban areas increased from $52 \%$ to $62 \%$ in the same period. These statistics are derived from the research conducted by Turok (2012:13), who argues that South Africa is one of the most populous and rapidly urbanising countries. The relevance of migration and urbanisation to this article lies in the fact that, whilst it is mostly young people who migrate to cities and towns, hunting for work and more conducive life circumstances, many members of the older generation prefer to remain in the rural areas and are therefore left in solitude, receiving only occasional visits in the villages from young people. Bohman et al (2007:352) clarify this relationship by 
showing that young and middle class people are often forced to migrate to urban centres in search of job opportunities, leaving the aged in rural areas to face a life of loneliness and alienation.

As May (2003:18) points out: the extended family is an important safety net for elderly black African people. The rapid rate of urbanisation of young people, seeking employment and education, therefore isolates elderly people from their children, and leaves them to live a solitary life (Ramashala 2014:2).

\section{Abuse of elderly people}

According to Sheldon (2011:5) one 80 year old woman was locked (by her own son) in a windowless room without any running water or electricity for almost a year where she received food every fourth day. The violation of older persons' human rights is escalating as many of them are forced to change their property ownership to children and relatives, whilst others are raped and even killed.

Ferreira and Lindgren (2008:98) define elderly abuse as 'the maltreatment of an aged person or any other infliction of physical, mental or financial power on an aged person which adversely affects that person'. De Haan (2005:165) observes that abuse of elderly people is a widespread problem that arises from a number of factors, including their children's need to share in their pension. Baloyi (2010:4) quotes Calvin Sengani (a former police commissioner in Limpopo), who stated that some 4810 rape cases of women and children had been reported in 2002 in Limpopo alone. In that report he added that a 75-year-old woman had also been raped by a 25 -year-old. For this article it is important to note that this crime of violence is also aimed at elderly persons (Ferreira \& Lindgren 2008:98). This is a clear indication of the need to ensure the security of the old aged in this country particularly in rural areas, where they can easily become targets of rapists and thugs.

Elderly people are also sometimes physically and emotionally abused by their children or relatives. Brennan and Heiser (2004:57) report that the predominant types of abuse are physical, psychological and financial. Such abuse is often accompanied by neglect in the form of refusal or failure to provide older people with necessities such as food, shelter, clothing, comfort and hygiene.

Some families are so poor that they simply have no resources to help elderly people, whilst others are guilty of deliberate neglect. In some cases, family members say that they find elderly people stubborn and difficult to deal with, whilst others argue that they receive a pension and so should be able to take care of themselves (Ferreira \& Lindgren 2008). This kind of betrayal and neglect often causes emotional distress for older people and undermines their trust in young people. African Eyes News Service (AENS 2014:6) reported that a certain grandmother and a pensioner in Motlatse village, outside Acornhoek in Mpumalanga was raped by her own nephew. This suggests that, although many similar cases are not reported, violence against elderly people is a global phenomenon (Gillam 2014).

\section{A pastoral theological reflection Introduction}

Despite of the fact that elderly people's challenges need to be approached from different perspectives within different disciplines, it is the intention of this article to primarily approach these problems from the theological point of view. Not only because the author is a theologian, but also because theology needs to play its part in eradicating challenges encountered by elderly people in our country. This does not intend to undermine other disciplines, which try to focus on this area, but it is to accept that this problem can be attended to in a multidisciplinary fashion - theology included.

\section{Health care}

We observe that elderly people may require access to good information about healthy eating habits. Such information could be provided by their medical doctor or could be accessed by relatives who are knowledgeable in this area. Elderly people also need to be told about the importance of exercise for their own health, according to National Institute on Aging (2008:6). This function could be carried out by clubs for elderly people, as it will be discussed in more detail later on in this article.

Access to good health care is a key factor in helping older people to continue playing an active role in their communities. Unhealthy people, whether old or young, are usually not able to make active contributions to their communities. Health care chaplains, in collaboration with ministers, pastors and elders, have an important role to play in ensuring that every elderly person gets access to proper health care, which is offered by the South African government for its senior citizens. The author fully agrees with Theron (2014:14) that the role of the government in this regard must be to ensure that they increase welfare grants to ensure that health care services and facilities for elderly people are accessible.

\section{The role of the church through its pastoral services}

It is, amongst others, primarily the church's responsibility to care for and to teach the younger generation about elderly people. The church cannot afford to continue turning a blind eye on the challenges face by older people. Hence, Klein (2009:36) is correct when he argues that the church is anointed and called to meet the needs of elderly people in the context in which it exists and serves. The church should, through its services, show the compassion Jesus Christ had for people - elderly people included. That is the reason why the working group on Biotechnology and Bioethics, in collaboration with the Society Commission of the Conference of European churches, went out to produce a document in the form of an article to elaborate on how churches should 
get involved in the lives of elderly people. Christian churches like Anglican, Baptist, Lutheran, Methodist, Orthodox, Reformed Old Catholic and Pentecostal Churches met and complied 'Ageing and Care for the elderly'. This is the kind of formation South African churches should have in order to be able to address the plight of our own elderly people. Jesus, the founder of the New Testament Christian church, showed his empathy with the elderly in many occasions, including healing the man who was sick and lying at the pool for 38 years. The man was not 38 years old, but his sickness was suggesting that he was an old man (Jn 5:5). It is remarkable that, even though many other people were sick around the pool, Jesus' attention was taken by this old man.

The biblical principle of 'love your neighbour as you love yourself' (Mt 22:39) should be the basis of all relationships including how we relate to elderly people. This is the kind of the attitude that can urge the church to seriously consider the importance of reaching out a hand to the neglected and mistreated elderly people. Another compelling force for the church to have this attitude is that every human being was created in the image of God (Gn 1:26-27). Jesus emphasised a special obligation of care towards the poor and the weak. In addition, this context also demands the commandment, which calls for 'Honor to father and mother' (Ex 20:12; Dt $5: 16)$. This commandment was given to counter the historical tendencies of seeing the older people as a burden, because they were no longer useful to bring bread on the table.

The commandment of honour and love towards our elderly people connects very well with the exhortation that Paul gave to Timothy about elderly men. He said to him: 'Do not rebuke an older man harshly, but exhort him as if he were your father' (1 Tm 5:1). The 'older men' in this context does not refer elders in terms of church office, but older with regard to age. This means that Paul was able to identify the difference when one addresses the older people from the younger ones. 'Not harsh' links to 'being gentle', suggesting that honour and respect should prevail when elderly people are to be conversed with. This responds directly to the issue of elderly abuse mentioned previously in this article. Some of the attributes that form the backbone of our moral life, honour, respect and gentleness, can help us reverse the damage that resulted from the abuse of the elderly people. It is the church, amongst other organisations, that can ensure that such teaching is held in high esteem in order to redeem the image of African people damaged by violent acts towards old people. These biblical principles summarised the agreement between Shongwe (2012) and Theron (2014) that the church should speak out (or teach) against the evils in the socio-political, economic and cultural spheres. This teaching should go beyond the church boundaries when pastors are addressing the community in its different kinds of gatherings such as indabas and other traditional meetings.

Waruta and Kinothi (2000:211) suggest that retired people should remain in the church's ministry wherever possible. In this view, the church would remain a locus - not only of conversations about elderly people, but also of the assurance that they are still part of society and also taken care of.

A positive possibility offered by the South African context is that old(er) age is often regarded as a blessing, because elderly people are considered a repository of wisdom - in oral form in particular. Although the topic on intergenerational ministry can be reserved for another research, it is important to mention that it was for this reason that the Older Persons Act describes ageing people as 'important sources of knowledge, wisdom and expertise' (Republic of South Africa 2006:10). Church life involves numerous activities, including dedicated services for women, men and the youth, but these should be extended to include the old aged. The church should also offer specialised programmes for elderly people, and invite health practitioners, social workers and other professionals to speak to them about age-relating issues such as the challenges they face and ways to overcome them. It is partly the responsibility of the church to create, amongst other things, the circumstances in which elderly people may have the frequent company of family and friends. The church, through its pastoral leadership, should encourage children, grandchildren and other family members to make time to visit or take elderly people out at times. According to Mintle (2011:1) one Christian pastor who tried to make time to take elderly people out for breakfast made a significant contribution to their happiness and the feeling of being acceptable in the society.

Another important role of the church in this regard is to encourage and train volunteers to visit the lonely ageing person and provide the spiritual and mental support. This kind of approach will help giving church deacons and elders the opportunity to also concentrate on other church business, whilst the volunteers assist with these regular visits. Parishes and other Christian organisations that work hand in hand with the particular local church can develop a few programs in which the active involvement of the elderly people can be possible. In other words, it is the duty of the church to ensure that elderly people feel being part of those Jesus promised to give life in abundance, irrespective of their age (Jn 10:10). Another important recommendation is that, in addressing the core problems relating to the challenges faced by elderly people, the church, education system, media and government should work together and support each other (Theron 2014).

How can the church contribute to ensure that elderly people are able to enjoy the full benefits of their pensions, whilst, at the same time, ensure that the problems of poverty are also addressed? One suggestion would be that the church, working in co-operation with the Department of Social Welfare, could help to identify the parents of children who are under the care of elderly people. Fathers who have abandoned their children should be called to account. The church's diaconal services and other related bodies should take care of the orphans in order to relieve the load on the pension of the older people. It is primarily the duty of the church's diaconal services to raise money and take care of those people who are in poverty - orphans in this particular 
context. It is still possible that through collaboration with NGOs as well as other business the diaconal office of the church can ask donations and gifts to care for the needy orphans and deserted children. The choosing of the seven men in the Apostolic church, as mentioned in the book of Acts, was initially for this purpose (Ac 6:3). Likewise, the problem of unemployment, as mentioned above, can also be treated in the same manner. To extend the helping hand to the unemployed, the church can assist people in finding jobs and employment. It is of course a big challenge, considering the socio-economic politics of our country, but it is the duty of the church to encourage people to find a job, even if it is less paying. The deacons and other selected people in the church may keep an eye on checking with members of the church who could offer some small job opportunities to these identified people. The church could also encourage relatives of the aged to visit them regularly. Traditionally, the greatest need of an older person is to receive visits. Roos and Malan (2012:2) emphasise the importance of families as caretakers to the homebound senior people.

On the subject of accusing elderly people of witchcraft, Exodus 22:18 teaches that we should not suffer the witch to live. The argument is not whether the accusations are true or false, but it is about the attitude we should have towards the accused people. Firstly, the biblical teachings condemn the actions that are often practically taken towards the suspects. Secondly, according to Baloyi (2010:4) every person deserves to be loved and embraced by the church. Thirdly, in more than one occasion the Bible teaches us not to be judges of other people. Matthew 7:1 and James 4:12 are some of the known scriptures that condemn any act of making ourselves judges towards other people - elderly people included. The church must not shy away from condemning these kinds of unfair judgements in their teachings. People must be taught to love one another.

The church can also help the community to form forums as well as day care centres, which will assist to ensure the safety as well as the welfare of the elderly people in their communities. Because not many black people want to be separated from their families and communities, it is the responsibility of the church in co-operation with the community and through its forums to start daily centres in which elderly people's counselling, security and welfare can always be monitored. The involvement and participation of one's family in African context is very crucial in assisting elderly people on many issues, including the issue of loneliness. The presence of the family members in all aspects that deals with elderly people brings more relief. That is why big families are encouraged it is expected from the children to take care of the parents when they grow old (Mbiti 1991). Even if the social workers and other people come to the rescue of a lonely old person, the real satisfaction will only come on the arrival of a close family member - a child in particular. That is why the church must acknowledge the importance of encouraging the relationships within the family. In this way the church will be working hand in hand with the community and family to meet the needs of their own context (Klein 2009).

\section{Clubs or meetings for elderly people}

The church as well as other Christian based organisations such as Hospivision (based on Steve Biko hospital in Tshwane), may extend their wings to have projects, which deal specifically in helping elderly people to gather at a certain point. Churches may learn from the Evangelical Lutheran church in Finland, which started a Common Responsibility fund raising, which targeted at alleviating loneliness amongst ageing as well as helping elderly people beyond the state's provision of social services. Even though these services can be initiated by the church, there is more than one way to open them up for all aged people regardless of their religion for the sake of their togetherness and sharing issues of old age.

Roos and Malan's (2012:1) research focused on the loneliness of elderly people in the context of institutionalised care, but there is no argument against the fact that loneliness also affects elderly people who are not in any institution. For this reason, elderly people need to be brought together to learn to limit the challenges that come with loneliness. It is evident that elderly people would not feel so lonely if they could share their feelings with other people of their own age group.

One inspirational example can be found in the story of Vakhegula-Vakhegula, a soccer team in Limpopo consisting of elderly women who meet to play soccer and share the joys and sorrows of their lives. Fihlani (2009:1) reports that the soccer team has about 40 members and meets twice a week for an hour's practice. One of the team members reported on the improved health she enjoyed after starting to play soccer. Although this team is not only composed of Christians, the fact that the team manager who started it is a Christian is something that the church can be proud of. My argument is that, directly or indirectly, the church must involve itself with the gathering of elderly people in order that its prophetic voice against the ills of the community can be addressed in a Christian manner.

There are many other ways, formal and informal, to gather elderly people. Programmes could provide religious instruction, pastoral care and social services. This is in line with the argument of Brunsdon and Lotter (2008:286), who say that retirees must be encouraged, or indeed challenged to find ways to integrate their life experiences with those of other people.

\section{Considerations for pastoral care givers when visiting and counselling elderly people}

For Malan and Dreyer (2009:202), pastoral care has an important role to play in engaging elderly people who are deeply affected by changes in their environment and society. Indeed, their study is an excellent example of the way sociology and pastoral care can work together in a multidisciplinary fashion to address the plight of elderly people in a South African context. It should, however, be acknowledged that, because African people do not believe 
in individualisation, any kind of pastoral counselling should accommodate their communal and extended family life. The saying 'I am because we are' informs us that they share almost everything in this life; hence, their challenges will not be unique.

Two ways that can assist in the elimination of the abuse of elderly people are, firstly, because black people have the spirit of Ubuntu, the communities in which elderly people could be victims of assault should ensure that they have forums through which they can improve the security of elderly people. These forums should organise regular visits to check the wellbeing of the elderly people who are sometimes staying alone or perhaps with some grandchildren. It is the duty of the forum to also make sure that the perpetrators of abuse are reported and justice should take place. Secondly, the communities can also initiate day care centres where elderly people can be taken care of. I agree with Theron (2014:6) on the fact that it is sometimes the conditions in which elderly people find themselves that makes them vulnerable to abuse, robbery and even murder. Dr Leon Klein, in his book entitled Centres of healing (2009), also give directions on how the local communities and churches can start centres of healing. The research also indicates that, whilst some elderly people continue to enjoy the traditional respect from the younger generation, there is also a growing trend towards violence against and abuse of elderly people, often perpetrated by members of the family (Legido-Quigley 2003:12). We can also observe that regular visits by relatives can help to ensure that elderly people do not feel isolated. Social contact is always a crucial part of psychological and, overall, health. In the words of Kirkwood (2005:41): 'Lay visitation to the elderly is more than a "do good" piece of social involvement. It is a serious commitment the church accepts on behalf of Christ.' Kirkwood (2005:41) argued that everyone, from families to the entire community, should collectively take charge of ensuring the safety and protection of our elderly people.

This is perhaps in line with the issue of elderly people who do not want to move out of their society to join their children in towns and cities, but prefer to remain in their respective communities. Any kind of counselling, which will attempt to deal with an individual in African context, may fail, because African people cannot be dealt with in isolation. I support Msomi (2008:221) when he argues that the therapy in African context must always take the community and the extended family seriously. This is why, if one needs to be successful in dealing with African elderly people's problems, one must be serious to accommodate the spirit of Ubuntu and the context of helping them within their particular environment. Every ministry should attempt to minister people within the context they find themselves (Msomi 2008:206). Kirkwood (2005:71) argues that a number of aspects must be understood by people who are preparing to undertake pastoral visits to elderly people. His recommendation is: 'Be sure your head is filled with a genuine desire to help them and your soul is filled with the love of representing God before others.' Kirkwood discusses the situation of elderly people in another continent, but the discussion is also valid in South Africa with regard to black South Africans. Regardless of context, elderly people will always need some kind of love and a degree of patience.

Elderly people need someone who will listen to them and appreciate what they have to say. The pastoral visitor must be ready to listen and to be appreciative, rather than critical. He or she should listen to their stories with acceptance and avoid lengthy Bible reading and prayers. The pastoral counsellor needs to realise that the narrative approach will work in the favour of e elderly people, because, by telling their stories, they gain courage in life. This is very important, because some elderly people lost their mobility, hearing and sight and they therefore cannot be attentive for longer periods. This approach receives support from Brunsdon and Lotter (2008:285) who acknowledges that it is through narrative that elderly people gets the opportunity to tell their problem-saturated stories, which becomes therapy for them. Dealing with elderly people also requires relevant training (Kloppers, Van Dyk \& Pretorius 2015:249).

De Haan (2005:162) makes a similar suggestion, arguing that elderly people should remain important members of the community and should not suffer any loss of status in African tribal society where the dominant family structure is that of the extended family. They should be considered an integral part of the church community and their wisdom, gathered through life experience, should be utilised.

For cultural and traditional reasons, I fully support the view of Arber and Evandrou (1993:170) that the providing of support to elderly people, will sometimes require that they will be divided into groups that can be cared for in a communal setting such as a ward or centre. This would mean that pastoral caregivers' visits would occur in a context in which elderly people have a sense of togetherness and the knowledge that they share things in common.

\section{Conclusion}

The elderly people in South Africa, particularly black people, are exposed to exploitation, abuse, violence and other forms of sufferings. The moral decay as well as the socio-economic situation is often to blame for their plight. Poverty, HIV and AIDS and other related factors plays a big role in subjecting elderly people to different forms of abuse and neglect. On the other hand their health conditions are also very worrisome. Their worth in society is often minimised and undermined. It is therefore primarily the duty of the church to retain their dignity by protecting and ensuring that they receive proper care. To achieve these, the church needs to work hand in hand with the education system, media, government and other NGOs. It is very important that the church must no longer turn its blind eye towards the challenges this group in our society are facing. The health care institutions, social workers and community, at large, should collaborate with the church through its pastoral care and counselling services 
to curb the practices that surface the exploitation and the subjection of our senior citizens. Their God-given human worth, place and status must be protected and preserved at all cost.

\section{Acknowledgements Competing interests}

The author declares that he has no financial or personal relationships which may have inappropriately influenced him in writing this article.

\section{References}

African Eyes News Service (AENS), 2014, 'Raped gogo says a cop leaked video of evidence', Daily Sun, 05 September, p. 6.

Arber, S. \& Evandrou, M. (eds.), 1993, Aging, independence and the life course Cromwell Press, Melksham, Wiltshire.

Baloyi, E., 2010, 'An African view of women as sexual objects as a concern for gender equality: A critical study', Verbum et Ecclesia 31(1), Art. \#380, 6 pages. http:// dx.doi/org/10.4102/ve.v31i1.380

Bigombe, B. \& Khadiagala, G.M., 2003, Major trends affecting families in sub-Saharan Africa, viewed 18 June 2005, from http://www.un.org/esa/socdev/family/ Publications/mtrendsbf.htm/

Bohman, D.M., Vasuthevan, S., Van Dyk, N.C. \& Ekman, S., 2007, “"We clean our houses, prepare for weddings and go to funerals": Daily lives of elderly Africans in Majaneng, South Africa', Journal of Cross Cult Gerontol 22, 323-337. PMID: in Majaneng, South Africa', Journal of Cross Cult Geront
17616794, http://dx.doi/org/10.1007/s10823-007-9040-8

Brennan, M. \& Heiser, D. (eds.), 2004, Spiritual assessment and intervention with older adults. Current directions and applications, The Hartworth Pastoral Press, New York.

Brunsdon, A.R. \& Lotter, G.A., 2008, 'Aftrede as intergrasionele taak', Koers - Bulletin for Christian Scholarship 73(2), 283-302.

Conradie, G. \& Charlton, K., 1992, Malpractices and mistreatment of residents in homes of the aged: Report on a think-tank, HSRC/UCT Centre of Gerontology, University of Cape Town, Cape Town.

Davey, J., 2006, “'Ageing in place", The views of older homeowners about housing maintenance, renovation and adaptation', Social Policy Journal of New Zealand 27, 128-141.

De Beer, E.J., 2011, "n Teologiese-etiese beoordeling van aftrede', In die Skriflig/In Luce Verbi 45(4), 803-823. http://dx.doi/org/10.4102/ids.v45i4.203

De Haan, M., 2005, The health of Southern Africa, 9th edn., Juta, Cape Town.

Dreyer, J.S. \& Van der Ven, J.A. (eds.), 2002, Divine justice - Human justice, Institute for Theology and Religion, Unisa, Pretoria.

Dovlo, E., 2007, 'Witchcraft in contemporary Ghana', in G. Ter Haar (ed.), Imagining evil: Witchcraft beliefs and accusations in contemporary Africa, pp. 76-112, Africa World Press Inc., Trenton, NJ.

Ernest, M.Z., 2003, 'The effects of divorce in South African community with specific reference to Esikhawini in KwaZulu Natal', MA dissertation, Dept. of Sociology, University of Zululand.

Ferreira, M. \& Lindgren, P., 2008, 'Elder abuse and neglect in South Africa: A case of marginalization, disrespect, exploitation and violence', Journal
of Elder Abuse \& Neglect 20(2), 91-107. PMID: 18928211, http://dx.doi/ of Elder Abuse \& Neglect 20(2)
org/10.1080/08946560801974497

Fihlani, P.S., 2009, Africa's football 'grannies' look to World Cup, viewed 14 May 2014 from http://news.bbc.co.uk/2/hi/africa/8389067.stm

Gillam, S., 2014, 'World elder abuse day: I went to interview an older woman but she had been killed for her land', [blog], viewed 14 April 2015, from www.helppage.org

Gordon, D., 2013, Monitor warns on housing lag, viewed 13 February 2014, from www.grocotts.co.za

HelpAge n.d., Older people in Africa: A forgotten generation, viewed 30 March 2015, from www.helpage.org

Hosegood, V. \& Timaeus, I.M., 2006, 'HIV/AIDS and older people in South Africa', in NCBI Bookshelf, A service of the National Library of Medicine, National Institutes of Health, National Academic Press, Rockville Pike, Bethesda, viewed 29 April 2014, from www.ncbi.nlm.nih.gov

Joubert, J. \& Brandshaw, D., 2005, 'Population aging and health challenges in South Africa', in Chronic Diseases of lifestyle in South Africa since 1995-2005, viewed 12 May 2014, from www.mrc.ac.za/chronic

Joubert, J., Swart, D. \& Reddy, S.P., 1998, Knowledge, perceptions and needs of older persons with reference on the cape flats, Institute for Aging in Africa, University of Cape Town, Cape Town, viewed 15 April 2015, from www.insituteofaging.uct.ac.za

Khomo, T., 2014, 'Masisizane. Times are tough, but together there is always hope', Daily Sun, 04 July, p. 14

Kinsella, K., \& Ferreira, M., 1997, 'Aging trends: South Africa', Department of Commerce, Bureau of the Census, Washington, DC, [blog], viewed 29 April 2014, from www.ncbi.nlm.nih.gov
Kirkwood, N.A., 2005, Pastoral care to the aged. Handbook for visitors, Morehouse Publishing, Harrisburg.

Klein, H.L., 2009, Centres of healing, AcadSA Publishing, Kempton Park, Johannesburg.

Kloppers, J.M., Van Dyk, A. \& Pretorius, L., 2015, 'The Experiences of the elderly and caregivers in respect of caring for the elderly in Windhoek and Rehoboth Namibia: An exploratory and descriptive study', Open Journal of Nursing 5, 246259. http://dx.doi/org/10.4236/ojn.2015.53029

Lam, M., Leibbrandt, G. \& Ranchhod, V., 2006, 'Aging in Sub-Saharan Africa: Recommendation for Furthering Research. Labourforce withdrawal of the elderly in South Africa', [blog], viewed 15 October 2015, from www.ncbi.nlm.nih.gov.

Langa, E., 2014, 'I stopped waiting for my RDP house. Now Madala's a healthy man', Daily Sun, 16 May, p. 7.

Larney, T. \& Lotter, G.A., 2005, 'Ouers se rol in die oordrag van etiese en morele waardes', Koers - Bulletin for Christian Scholarship 70(4), 661-684. http://dx.doi/ org/10.4102/koers.v70i4.287

Legido-Quigley, H., 2003, 'The South African Old pension: Exploring the role on poverty alleviation in households affected by HIV/AIDS', paper presented at the 4th International Research Conference on Social Security, University of Manchester, Manchester, 5-7 May.

Malan, E. \& Dreyer, Y., 2009, 'Multidissiplinere beskouinge op veroudering vanuit 'n pastorale perspekief', HTS Teologiese Studies/Theological Studies 65(1), 200-208. http://dx.doi.org/10.4102/htsv65i1.182

May, J., 2003, Chronic poverty and older people in South Africa, CPRC Working Paper 25, Chronic Poverty Research Centre, HelpAge International.

Mbiti, J.S., 1991, Introduction to African Religion, Heinemann Educational Publishers, Sandton, Johannesburg.

Mintle, L., 2011, 'Pastoral care to the elderly is still needed. Doing life together', [blog], viewed 3 June 2015, from www.beliefnet.com

Moller, V. \& Sotshongaye, A., 1996, "My family eat this money too": Pension sharing and self-respect among Zulu Grandmothers', Southern African Journal of Gerontology 5(2), 9-19.

Msomi, V.V., 2008, Ubuntu contextual African pastoral care and counselling, CB Powe Bible Centre, Unisa, Muckeneuk, Pretoria.

Myeza, P., 2010, Pensioners' financial woes demonstrate the importance of retirement planning, viewed 31 March 2015, from www.lexisnexis.co.za

National Institute on Aging, 2008, Talking with your older patient: A clinical handbook, Department of Health and Human Services, Bethesda.

Ramashala, M.F., 2014, 'Living arrangements, poverty and the health of older people in Africa', Population Bulletin of the United Nations 19, 1-18.

Republic of South Africa, 1996, The constitution of the republic of South Africa, Act 108, Government Printer, Pretoria.

Republic of South Africa, 2006, Older Persons, Act 13, Government Printer, Pretoria

Roos, V. \& Malan, L., 2012, 'The role of context and the interpersonal experience of loneliness among people in a residential care facility', Global Health Action 5, 1-2. PMID: 23078747, http://dx.doi/org/10.3402/gha.v5i0.18861

SA Hospital Plan, 2005, Hospital plans for pensioners and senior citizens, viewed 31 March 2015, from www.sahospitalplan.com

SAinfo Reporter, 2014, South Africa two-third urbanized, viewed 30 April 2014, from www.southafrica.info/new/urbanisation

Shefer, T. \& Clowes, L., 2012, 'Talking South African fathers: A critical examination of men's constructions and experiences of fatherhood and fatherless', South African Journal of Psychology 42(4), 536-553.

Sheldon, M., 2011, 'Report on locked-up gran goes to DeLile', Cape Argus, 17 January, p. 5.

Shongwe, V., 2012, 'Church must rediscover its prophetic voice over social ills', Sunday Independent, 23 September, p. 17.

Sibiya, P., 2014, 'God saved me from attackers', Daily Sun, 17 June, p. 4.

Steyn, T.H. \& Masango, M.J., 2011, 'The theology and praxis of practical theology in the context of the faculty of theology', HTS Teologiese Studies/Theological Studies 67(2), Art. \#956, 7 pages. http://dx.doi/org/10.4102/hts.v67i2.956

Summers, D. \& Gadsby, A., 2001, Longman dictionary of contemporary English, 3rd edn., with New words suppl., Pearson Education Limited, Edinburgh, Harlow.

Theron, P.M., 2014, 'Being treated like "waste" during the golden years: Practical theological perspective', HTS Teologiese Studies/Theological Studies 70(2), Art. \#2636, 9 pages. http://dx.doi/org/10.4102/hts.v70i2.2636

Thukwayo, K., 2014, 'No food for six days', Daily Sun, 04 July, p. 15.

Turok, I., 2012, Urbanisation and development in South Africa: Economic imperatives, spatial distortions and strategic responses emerging population issues, Working Paper 8, International Institute for Environment and Development, London, viewed on 14 October 2015, from www.pubs.iied.org

Waruta, D.W. \& Kinothi, W.K., 2000, Pastoral care in African Christianity, Acton Press, Nairobi.

Worsfold, B.J. (ed.), 2005, Women aging. Literature and experience, University of Lleida, Lleida

World Health Organisation, 2015, Ageing and life course, WHO, Geneve.

Zingoni, T.S., 2014, 'Diving into the South African grant system', Population and employment statistics, News 24 , [blog], viewed 15 April 2015, from www.news 24 .
com 